\title{
References
}

1. Hrytsynyak I. I. Lipid metabolism in fish: monogr. / [I. I. Hrytsynyak, K. B. Smolyaninov, V. G. Yanovich] — Lviv : "Triada plus", 2010. - 335 p. (in Ukrainian)

2. Gringevsky M. V. The intensification of aquaculture production in midi-Ukrainian ponds // Kyiv : Svit, 2000. — 183 p. (in Ukrainian)

3. Keits M. Lipidology // Moscow., 1975. — 260 p (in Russian).

4. Xue C. ntioxidative activity of carp blood plasma on lipid peroxidation / C. Xue, G. Yu, T. Hirata et al. // Biosci. Biotechnol. Biochem. - 1998. - 62(2). - P. 201-215.

5. Pylypets A. Z. Biochemical composition, synthetical and energetical processes in skeletal muscles of carp of different age at the end of summer and: Autoref of candidate thesis. : 03.00.04 "Biochemistry — Lviv, 2003. — 16 p. (in Ukrainian)

Рецензент - О. С. Грабовська, к. б. н., с. н. с., ІБТ НААН.

УДК 636.2:636.084

doi: $10.36359 /$ scivp.2019-20-2.08

\section{МОЛОЧНА ПРОДУКТИВНІСТЬ КОРІВ ЗА ВИКОРИСТАННЯ У РАЦІОНАХ ЗИМОВО-СТІЙЛОВОГО ПЕРІОДУ УТРИМАННЯ ВИКО-ЯЧМІННОГО СИЛОСУ}

\author{
Н. М. Федак, канд. біол. наук, с. н. с., \\ I. В. Душара, канд. с.-г. наук
}

Інститут сільського господарства Карпатського регіону НААН

вул. Грушевського, 5, с. Оброшино, Пустомитівський р-н, Львівська обл., 81115, Україна

Показана ефективність згодовування дійним коровам вико-ячмінного силосу (порівняно з кукурудзяним) із нових сортів кормових культур у складі силосно-концентратнокоренеплідного раціону в умовах Карпатського регіону.

Встановлено, щзо використання силосу, заготовленого із озимих ячменю (сорт Широколистий) та вики (сорт Львів'янка) забезпечує потребу дійних корів, згідно з нормою за низкою важливих параметрів живлення (протеїн, Кальцій, Фосфор, Сірка, Мідь, Цинк, Кобальт, Йод). Це сприяє інтенсифікації метаболічних прочесів у рубиі та крові, поліпшує перетравність поживних речовин кормів, у результаті чого підвищується молочна продуктивність корів, якість молока і рівень рентабельності його виробництва.

Ключові слова: ДІЙНІ КОРОВИ, ГОДІВЛЯ, СИЛОС, МОЛОЧНА ПРОДУКТИВНІСТЬ, ЯКІСТЬ МОЛОКА.

Питання рентабельності молочного скотарства, поліпшення якості продукції та зниження іï собівартості тісно пов'язані із повноцінною годівлею худоби $[1,2]$. Основою раціонів для великої рогатої худоби у зимово-стійловий період утримання є силосовані корми. Їх якість - це один із визначальних факторів ефективного використання соковитих кормів у структурі раціонів, а звідси і реалізації генетичного потенціалу тварин. Нині в системі кормовиробництва спостерігається тенденція до зниження в структурі зимових раціонів 
частки сіна, а літніх - зелених кормів з одночасним збільшенням високоякісних силосу $\mathrm{i}$ сінажу. За таких умов виникає можливість впровадження сінажно-силосного типу годівлі, зокрема дійних корів - їх продуктивність не знижується, а навпаки має тенденцію до підвищення. Силос із кукурудзи - основної профілюючої культури для цього виду корму характеризується високим вмістом вуглеводів та нестачею протеїну й мінеральних речовин, які $є$ одними із основних каталізаторів обмінних процесів в організмі тварин, а отже і рівня їх продуктивності [3-6]. Крім цього, специфіка агроекологічних умов Карпатського регіону, а звідси періодично низька врожайність, висока енергоємність кукурудзи підвищує собівартість тваринницької продукції і вимагає рівнозначної заміни у кормовому клині зони [7-9]. Альтернативою цій культурі слугують сумішки злаково-бобових, зокрема 3 виведених в Інституті сільського господарства Карпатського регіону НААН України сортів озимого ячменю (Широколистий), який має добру облиствленість та високий вміст цукрів, i високобілкової озимої вики (Львів'янка) і відповідають вимогам до сумішок для заготівлі високопоживних силосів [10-12]. Дослідження з вивчення впливу згодовування силосу із цих культур на молочну продуктивність 3 економічним обгрунтуванням $є$ актуальними і мають вагоме значення в теорії й практиці годівлі жуйних.

Матеріали і методи. Метою нашої роботи було порівняльне вивчення впливу силосів із кукурудзи та новостворених сортів вики (Львів'янка) і кормового ячменю (Широколистий) у структурі силосно-концентратно-коренеплідних раціонів на молочну продуктивність корів та якісні параметри молока.

Дослідження проведено в зимово-стійловий період утримання, тривалістю 90 діб на двох групах корів-аналогів (походження, вік, жива маса, продуктивність), голштинізованої чорно-рябої породи по 10 голів у кожній (табл. 1).

Таблиия 1

Схема досліду

\begin{tabular}{|l|l|}
\hline \multicolumn{1}{|c|}{ Групи } & \multicolumn{1}{|c|}{ Характеристика годівлі тварин } \\
\hline Контрольна & $\begin{array}{l}\text { ОР: комбікорм К60-4-89, силос кукурудзяний, сіно злаково-бобове, буряки кормові, } \\
\text { солома озимої пшениці, меляса }\end{array}$ \\
\hline Дослідна & $\begin{array}{l}\text { ОР: комбікорм К60-4-89, силос вико-ячмінний, сіно злаково-бобове, буряки } \\
\text { кормові, солома озимої пшениці, меляса }\end{array}$ \\
\hline
\end{tabular}

Тип раціону - силосно-концентратно-коренеплідний. Технологія годівлі корів полягала у регульованому трикратному задаванні об'ємистої частини раціону (сіна злаково-бобового, соломи озимої пшениці, буряків кормових, силосу, меляси) і двократному - концентрованих (під час доїння) кормів. Спосіб утримання корів стійлово-прив'язний.

В основний період (90 діб) корови контрольної групи отримували раціон зрівняльного періоду, а дослідної - аналогічний раціон, у якому кукурудзяний силос було замінено викоячмінним.

Силос до складу раціонів включали з розрахунку 41-46 \% від загальної поживності. Годівлю корів проводили згідно із загальноприйнятими нормами $[3,4]$.

Протягом досліду вели щоденний облік середньодобових надоїв молока. Матеріалом досліджень слугувало молоко. У молоці визначали: вміст сухої речовини шляхом висушування до постійної ваги; густину - за допомогою ареометра-лактоденсиметра; кислотність - шляхом титрування; вміст золи - шляхом спалювання зразків у муфельній печі; кількість білка - за методом К'єльдаля; вміст жиру - кислотним методом за Гербером; концентрацію Кальцію - перманганатним способом, Фосфору - колориметрично [13].

Біометричну обробку результатів проводили за М. О. Плохінським, враховуючи критерій Стьюдента, з використанням стандартних комп'ютерних програм. Для встановлення ступеня вірогідності результатів використовували значення критерію при порогах вірогідності: * $-\mathrm{P}<0,05, * *-\mathrm{P}<0,01, * * *-\mathrm{P}<0,001$. 
Результати й обговорення. Застосування в складі силосно-концентратнокоренеплідних раціонів дійних корів у зимово-стійловий період утримання кукурудзяного $і$ вико-ячмінного силосів суттєво вплинуло на молочну продуктивність корів та якісні показники молока (табл. 2).

Табличя 2

Молочна продуктивність корів $(\mathrm{M} \pm \mathrm{m}, \mathrm{n}=10)$

\begin{tabular}{|c|c|c|}
\hline \multirow{2}{*}{ Показники } & \multicolumn{2}{|c|}{ Групи } \\
\cline { 2 - 3 } & контрольна & дослідна \\
\hline Загальний надій молока, кг & & $1827,0 \pm 23,87 * * *$ \\
\hline натурального & $1683,0 \pm 12,22$ & $1717,4 \pm 27,74 * * *$ \\
\hline 4 \% - жирності & $1514,7 \pm 16,61$ & $20,3 \pm 0,27 * * *$ \\
\hline Середньодобовий надій молока, кг: & & $19,1 \pm 0,31^{* * *}$ \\
\hline натурального & $18,7 \pm 0,14$ & $16,8 \pm 0,18$ \\
\hline 4 \% - жирності & & \\
\hline
\end{tabular}

За 90 діб облікового періоду загальний надій натурального молока на 1 голову в контролі становив 1683,0, у досліді - 1827,0 кг. Різниця між групами склала 144,0 кг, або 8,6 \% (P<0,001). За перерахунку молока на 4,0 \% жирність надій у контрольній групі становив 1514,7 кг проти 1717,4 кг у дослідній. Різниця між групами за цим показником склала 202,7 кг $(13,4 \%)$ і є вірогідною $(\mathrm{P}<0,001)$.

Середньодобовий надій натурального молока на 1 голову протягом експерименту в контрольній групі становив 18,7 кг, у дослідній - 20,3 кг і був вищим на 1,6 кг (8,6 \%) $(\mathrm{P}<0,001)$. За перерахунку молока на $4,0 \%$ жирність добовий надій у контрольній групі був на рівні 16,8 кг проти 19,1 кг у дослідній з перевагою 2,3 кг, або 13,7\% (Р<0,001).

Аналіз якісних показників молока (табл. 3) засвідчує перевагу дослідної групи щодо контрольної. Зокрема, вміст жиру у молоці корів на контролі становив 3,60 \%, у досліді - 3,76 $\%$, що було більше на $0,16 \%(\mathrm{P}<0,05)$, кількість білка відповідно по групах становила 3,30 \% і $3,46 \%$. Різниця склала $0,16 \%(\mathrm{P}<0,01)$.

Хімічний склад молока корів $(\mathrm{M} \pm \mathrm{m}, \mathrm{n}=10)$

\begin{tabular}{|l|c|c|}
\hline \multirow{2}{*}{ Показники } & \multicolumn{2}{|c|}{ Групи тварин } \\
\cline { 2 - 3 } & I & II \\
\hline Суха речовина, \% & $12,0 \pm 0,06$ & $12,2 \pm 0,06^{*}$ \\
\hline Жир, \% & $3,60 \pm 0,04$ & $3,76 \pm 0,07^{*}$ \\
\hline Білок, \% & $3,30 \pm 0,02$ & $3,46 \pm 0,03^{* *}$ \\
\hline Молочний цукор, \% & $4,30 \pm 0,05$ & $4,32 \pm 0,07$ \\
\hline Зола, \% & $0,78 \pm 0,04$ & $0,83 \pm 0,04$ \\
\hline Кальцій, \% & $0,21 \pm 0,009$ & $0,25 \pm 0,008^{* *}$ \\
\hline Фосфор, \% & $0,22 \pm 0,013$ & $0,23 \pm 0,009$ \\
\hline Густина, $\Gamma^{\circ}$ см $^{3}$ & $1,028 \pm 0,001$ & $1,027 \pm 0,001$ \\
\hline Кислотність, ${ }^{0} \mathrm{~T}$ & $17,4 \pm 0,12$ & $16,9 \pm 0,14^{*}$ \\
\hline
\end{tabular}

Кількість сухої речовини у дослідній групі була на 0,2 \% вища, ніж у контролі $(\mathrm{P}<0,05)$. Кислотність молока тварин контрольної групи становила $16,9^{0} \mathrm{~T}$, дослідної - $17,4^{0} \mathrm{~T}$ з різницею $0,5^{0} \mathrm{~T}(\mathrm{P}<0,05)$. Абсолютні показники кислотності знаходилися у межах норми.

Відзначено тенденцію до збільшення вмісту молочного цукру і золи у молоці корів дослідної групи щодо контрольної, однак різниця була неістотною.

Рівень Кальцію в молоці у дослідній групі переважав аналогічний показник контрольної групи на $0,04 \%(\mathrm{P}<0,01)$. 
За густиною молока і вмістом у ньому Фосфору корови дослідної групи несуттєво переважають аналогічні показники тварин контрольної.

Різний рівень молочної продуктивності піддослідних тварин по-різному позначився на витратах кормових одиниць і перетравного протеїну на одиницю продукції. Зокрема, витрати кормових одиниць на 1 кг виробленого молока у контрольній групі становили 0,79 , а в дослідній - 0,78. Різниця склала 1,3 \%. Витрати перетравного протеїну на 1 кг молока у контролі - 71,0 г проти 77,0 г у досліді. Різниця у абсолютних величинах склала 6,0 г $(8,5 \%)$ на користь контрольної групи.

\title{
В И С Н О В К И
}

Таким чином, використання у годівлі дійних корів вико-ячмінного силосу підвищує середньодобові надої молока, його якісні показники (суху речовину, жир, білок) за практично однакових витрат корму на одиницю продукції, порівняно із кукурудзяним аналогом. У зимово-стійловий період утримання в умовах Карпатського регіону рекомендовано включати до складу силосно-концентратно-коренеплідного раціону силос, заготовлений із нових сортів озимого ячменю (Широколистий) та озимої вики (Львів'янка). У структурі кормосумішки на ячмінь має припадати $75 \%$, а на вику - $25 \%$. Відсоток компонентів раціону повинен у середньому становити (за поживністю): сіна $-8-9$, соломи $-1,5-2$, буряків кормових - 9-10, силосу вико-ячмінного - 41-46, комбікорму - 32-33, меляси - 2,0-2,5\%.

Перспективи досліджень. Проведені дослідження можуть слугувати теоретичною основою доцільності застосування у годівлі дійних корів у зимово-стійловий період утримання в умовах кормової бази Карпатського регіону силосу з нових сортів озимих вики $і$ ячменю. Це дасть можливість ефективно використовувати цей соковитий корм у раціонах тварин, тобто трансформувати його у продукцію (молоко) з високими якісними показниками і низькою собівартістю.

\section{MILK PRODUCTIVITY OF COWS BY USING IN RATIONS DURING WINTER-STALL PERIOD OF MAINTENANCE VETCH-BARLEY SILAGE}

\author{
N. Fedak, I. Dushara \\ Institute of Agriculture of the Carpathian region of NAAS \\ 5, Grushevskogo str., Obroshyno village, Pustomyty district, Lviv region, 81115, Ukraine \\ S U M M A R Y
}

The efficiency of feeding of the dairy cows by silage from new varieties of fodder crops (barley cv. Broadleaf and vetch cv. Lvivyanka) as a part of silage-concentrate-root ration in the conditions of Precarpathians area(comparatively to corn silage) are investigated and influence of its feeding on the milk productivity level and milk quality characteristics are also studied.

It was established that the total yield of natural milk per 1 head increased to $8,6 \%$, and in recount to fat content of $4,0-13,4 \%$; the average yield increased respectively by $8,6 \%$ and to $4,0 \%$ fat $-13,7 \%$.

Analysis of milk quality characteristics proves an advantage experimental group to control. In particular, the content of fat and protein in the milk of cows increased to $0,16 \%$. The part of dry matter increased to $0,2 \%$. Absolute acidity values were within normal limits. There was a tendency to increase the of milk sugar content and ash in the cows milk of experimental group. The content of calcium in the cows milk of the experimental group increased to $0,04 \%$. The milk of the experimental group cows dominated control by milk density and phosphorus content without reliable difference. 
The cost of feed units per $1 \mathrm{~kg}$ of milk produced in the experimental group were lower by 1,3 $\%$. The expenditure of digestible protein per $1 \mathrm{~kg}$ of milk in the control was $71,0 \mathrm{~g}$ vs. $77,0 \mathrm{~g}$ in the experiment. The difference in absolute values was $6.0 \mathrm{~g}(8.5 \%)$ in favor of the experimental group.

Thus, the use in feeding dairy cows vetch-barley increases the average daily milk yield and milk quality characteristics for almost the same cost of feed per unit, compared to corn analogue.

It was recommended adding to the structure of silage-concentrate-root ration of dairy cows in winter-stalled period of maintenance in the area of Precarpathians silage from the barley cv. Broadleaf and the vetch cv. Lvivyanka. In the structure of the feed mix for barley should be $75 \%$, and on the vetch $-25 \%$. In the average the component composition of the nutritional ration should consist of: hay $-8-9 \%$, straw $-1,5-2$, beet feed $-9-10$, vetch-barley silage $-41-46$, mixed fodder $-32-33$, molasses $-2-2,5 \%$. QUALITY.

Keywords: DAIRY COWS, FEEDING, SILAGE, DAIRY PRODUCTIVITY, MILK

\title{
МОЛОЧНАЯ ПРОИЗВОДИТЕЛЬНОСТЬ КОРОВ ПРИ ИСПОЛЬЗОВАНИИ \\ В РАЦИОНАХ ЗИМНЕ-СТОЙЛОВОГО ПЕРИОДА СОДЕРЖАНИЯ ВИКО- ЯЧМЕННОГО СИЛОСА
}

\author{
Н. Н. Федак, И. В. Душара
}

Институт сельского хозяйства Карпатского региона НААН

ул. Грушевского, 5, с. Оброшино, Пустомытовский р-н, Львовская обл., 81115, Украина

\section{А Н Н О Т А ЦИ Я}

Показана эффективность скармливания дойным коровам вико-ячменного силоса (по сравнению с кукурузным) с новых сортов кормовых культур в составе силосно-концентратнокорнеплодного рациона в условиях Карпатского региона.

Установлено, что использование силоса, заготовленного из озимых ячменя (с. Широколистый) и вики (с. Львовянка) обеспечивает потребность дойных коров согласно нормы по ряду важных параметров питания (протеин, кальций, фосфор, сера, медь, цинк, кобальт, йод). Это сопутствует интенсификации метаболических процессов, улучшает переваримость питательных веществ кормов, в результате чего повышается молочная производительность коров, качество молока и уровень рентабельности его производства.

Ключевые слова: ДОЙНЫЕ КОРОВЫ, КОРМЛЕНИЕ, СИЛОС, МОЛОЧНАЯ ПРОИЗВОДИТЕЛЬНОСТЬ, КАЧЕСТВО МОЛОКА.

\section{Л I T E P A T У P A}

1. Есауленко H. H. Оптимизация кормления высокопродуктивных коров / Н. Н. Есауленко, Н. А. Юрина, Д. А. Юрин // Научные основы повышения продуктивности сельскохозяйственных животных : Сб. науч. тр. СКНИИЖ. Краснодар, 2017. - Т. 2. - № 6. C. $154-158$.

2. Пышманцева H. А. Инновации в кормлении коров / Н. А. Пышманцева, В. В. Ерохин // Сб. науч. тр. ВНИИ овцеводства и козоводства. - Ставрополь, 2013. - Т. 3. - № 6. - C. 231-232.

3. Норми і раціони повноцінної годівлі високопродуктивної великої рогатої худоби : довідник-посібник / за наук. ред Г. О. Богданова, В. М. Кандиби. Київ, 2012. - 296 с.

4. Норми, орієнтовні раціони та практичні поради з годівлі великої рогатої худоби: посібник; за ред. I .І. Ібатулліна, В. І. Костенка. - Житомир: Рута, 2013. - 516 с.

5. Півторак Я. I. Організація виробництва молока при використанні комбінованих силосів / Я. І. Півторак, Н. М. Гордійчук, Л. Г. Воргуль // Науковий вісник Львівського 
національного університету ветеринарної медицини та біотехнологій ім. С. 3. Гжицького. 2007. - Т. 9, № 3 (34), Ч. 3. - С. 107-111.

6. Теорія і практика нормованої годівлі великої рогатої худоби / за ред. В. М. Кандиби, І. І. Ібатуліна, В. І. Костенка. - Житомир : Рута, 2012. - 860 с.

7. Вудмаска В. Ю. Урожай зеленої маси і якість силосованих кормів із нових сортів озимого ячменю і вики / В. Ю. Вудмаска, О. М. Заяць, І. В. Душара // Корми і кормовиробництво. - 2002. - № 48. - С. 187-190.

8. Гноєвий I. В. Ефективність виробництва молока у зв'язку з різним співвідношенням зелених кормів і силосу у раціонах нетелів і корів / I. В. Гноєвий, В. І. Гноєвий, Г. Н. Попова // Передгірне та гірське землеробство і тваринництво. - 2006. - Вип. 48, Ч. II. - С. 36-48.

9. Левицька Л. Г. Виробництво молока із використанням силосованих злаково-бобових сумішок / Передгірне та гірське землеробство i тваринництво. - 2016. Вип. 60. C. 190-197.

10. Душара I. B. Мікробіальний синтез протеїну в рубці дійних корів за згодовування кукурудзяного та ячмінно-викового силосів / I. В. Душара // Сільський господар. - 2007. № 9/10. - С. 12-14.

11. Душара I. В. Метаболічні процеси в організмі лактуючих корів за використання кукурудзяного та вико-ячмінного силосів у складі силосно-концентратно-коренеплідних раціонів / І. В. Душара // Сільський господар. - 2010. - № 7/8. - С. 10-13.

12. Степаненко В. Н. Рубцовый метаболизм и гематологические показатели разных силосов при использовании в кормовых рационах бычков / В. Н. Степаненко // Научнотехнический бюллетень Института животноводства НААН. - 2012. - Вип. 108. C. $102-106$

13. Кугенев П. В. Практикум по молочному делу // П. В. Кугенев, Н. В. Барабанщиков. М. : Агропромиздат, 1988. - 222 с.

\section{References}

1. Esaulenko N. N. Optymyzatsyia kormlenyia vysokoproduktyvnykh korov / N. N. Esaulenko, N. A. Yuryna, D. A. Yuryn // Nauchnye osnovy povyshenyia produktyvnosty selskokhoziaistvennykh zhyvotnykh : Sb. nauch. tr. SKNYYZh. Krasnodar, 2017. - T. 2. - № 6. - S. 154-158 (in Russian).

2. Pyshmantseva N. A. Ynnovatsyy v kormlenyy korov / N. A. Pyshmantseva, V. V. Erokhyn // Sb. nauch. tr. VNYY ovtsevodstva y kozovodstva. - Stavropol, 2013. - T. 3. - № 6. - S. 231-232. (in Russian).

3. Normy i ratsiony povnotsinnoi hodivli vysokoproduktyvnoi velykoi rohatoi khudoby : dovidnyk-posibnyk / za nauk. red. H. O. Bohdanova, V. M. Kandyby. Kyiv, 2012. - 296 s. (in Ukrainian).

4. Normy, oriientovni ratsiony ta praktychni porady z hodivli velykoi rohatoi khudoby: posibnyk; za red. I .I. Ibatullina, V. I. Kostenka. - Zhytomyr: Ruta, 2013. - 516 s. (in Ukrainian).

5. Pivtorak Ya. I. Orhanizatsiia vyrobnytstva moloka pry vykorystanni kombinovanykh sylosiv / Ya. I. Pivtorak, N. M. Hordiichuk, L. H. Vorhul // Naukovyi visnyk Lvivskoho natsionalnoho universytetu veterynarnoi medytsyny ta biotekhnolohii im. S. Z. Gzhytskoho. - 2007. - T. 9, № 3 (34), Ch. 3. - S. 107-111. (in Ukrainian).

6. Teoriia i praktyka normovanoi hodivli velykoi rohatoi khudoby / za red. V. M. Kandyby, I. I. Ibatulina, V. I. Kostenka. - Zhytomyr : Ruta, 2012. - 860 s. (in Ukrainian).

7. Vudmaska V. Yu. Urozhai zelenoi masy i yakist sylosovanykh kormiv iz novykh sortiv ozymoho yachmeniu i vyky / V. Yu. Vudmaska, O. M. Zaiats, I. V. Dushara // Kormy i kormovyrobnytstvo. - 2002. - № 48. - S. 187-190. (in Ukrainian). 
8. Hnoievyi I. V. Efektyvnist vyrobnytstva moloka u zviazku z riznym spivvidnoshenniam zelenykh kormiv i sylosu $\mathrm{u}$ ratsionakh neteliv i koriv / I. V. Hnoievyi, V. I. Hnoievyi, H. N. Popova // Peredhirne ta hirske zemlerobstvo i tvarynnytstvo. - 2006. - Vyp. 48, Ch. II. - S. 36-48. (in Ukrainian).

9. Levytska L. H. Vyrobnytstvo moloka iz vykorystanniam sylosovanykh zlakovo-bobovykh sumishok / Peredhirne ta hirske zemlerobstvo i tvarynnytstvo. - 2016. Vyp. 60. S. 190-197. (in Ukrainian).

10. Dushara I. V. Mikrobialnyi syntez proteinu v rubtsi diinykh koriv za zghodovuvannia kukurudzianoho ta yachminno-vykovoho sylosiv / I. V. Dushara // Silskyi hospodar. - 2007. - № 9/10. - S. 12-14. (in Ukrainian).

11. Dushara I. V. Metabolichni protsesy v orhanizmi laktuiuchykh koriv za vykorystannia kukurudzianoho ta vyko-yachminnoho sylosiv u skladi sylosno-kontsentratno-koreneplidnykh ratsioniv / I. V. Dushara // Silskyi hospodar. - 2010. - № 7/8. - S. 10-13. (in Ukrainian).

12. Stepanenko V. N. Rubtsovyi metabolyzm y hematolohycheskye pokazately raznykh sylosov pry yspolzovanyy v kormovykh ratsyonakh bychkov / V. N. Stepanenko // Nauchnotekhnycheskyi biulleten Ynstytuta zhyvotnovodstva NAAN. - 2012. - Vyp. 108. - S. 102-106 (in Russian).

13. Kuhenev P. V. Praktykum po molochnomu delu // P. V. Kuhenev, N. V. Barabanshchykov. - M. : Ahropromyzdat, 1988. - 222 s. (in Russian).

Рецензент - С. О. Вовк, д. біол. н, професор, завідувач лабораторії дрібного тваринництва Інституту сільського господарства Карпатського регіону НААН. 